\title{
The Interlanguage Interference on the Difficulties of Building Question Sentences by the Second Year Students of MA As Soorkaty Salatiga
}

\author{
Sari Famularsih \\ English Department of Educational Faculty \\ State Islamic Studies Institute (STAIN) Salatiga \\ Jl. Tentara Pelajar No. 2 Salatiga, Central Java, Indonesia \\ sarifamularsih01@gmail.com
}

\begin{abstract}
This study is aimed to elaborate the interlanguage interference of the difficulties which are faced by 40 second year students of MA As Soorkaty Salatiga in academic year of 2004-2005 in building question sentences and the sources of difficulties. The research is conducted by such kind of test. The total number of test are 20 items, consist of 5 yesno questions, $5 \mathrm{~W}-\mathrm{H}$ questions, and 10 tag questions which is done in a written essay form. Based on the analysis, the result shows some conclusions. Firstly, the researcher finds the types of difficulties problems are faced by the students in building question mastery, such as: (1) building yes-no question sentences in translation the word "apakah", that is related with the use of to be. (2) Building interrogative word question sentences in translation the words "apa", "kapan", "milik siapa", etc. That are related with the use of "what", "when", "whose", etc. (3) Completing the tag question sentences with the proper auxiliary based on tense of the sentences. The most difficulties in building question sentences are especially in yes-no question form by using the word "apakah". In the term of interlanguage, the students' errors are mostly included in expressing meaning by the words and grammar of the first language. The source of difficulties which have been analyzed are mostly caused by inter lingual and intra lingual transfer.
\end{abstract}


Keywords: Interlanguage, Question Sentence, Interlingual Transfer, Intralingual Transfer

\begin{abstract}
Abstrak
Penelitian ini bertujuan untuk menguraikan interferensi interlanguage dari kesulitan yang dihadapi 40 siswa kelas dua MA As Soorkaty Salatiga tahun ajaran 2004-2005 dalam menyusun kalimat tanya dan akar-akar kesulitannya. Penelitian ini dilakukan melalui tes dengan total 20 butir soal, terdiri dari 5 soal yes-no questions, 5 soal $W$-H questions, dan 10 soal tag questions yang dikerjakan dalam bentuk tes tertulis. Berdasarkan analisis, hasilnya menunjukkan beberapa kesimpulan. Pertama, peneliti menemukan kesulitan yang dihadapi siswa dalam menyusun kalimat tanya, seperti: (1) menyusun kalimat yes-no questions dalam terjemahan kata "apakah", yang berhubungan dengan penggunaan to be. (2) Menyusun kalimat tanya dalam terjemahan kata "apa", "kapan", "milik siapa", dll yang berkaitan dengan penggunaan "what", "when", "whose", dll (3 ) Melengkapi tag questions dengan tambahan auxiliary yang sesuai berdasarkan tense kalimat. Kesulitan yang paling sering dijumpai dalam menyusun kalimat tanya terutama pada yes-no questions dengan menggunakan kata "apakah". Berkaitan dengan tema interlanguage, sebagian besar kesalahan siswa adalah dalam mengungkapkan makna dengan kata-kata dan tata bahasa dari bahasa pertama. Akar kesulitan yang telah dianalisis sebagian besar disebabkan oleh interlingual transfer dan intralingual transfer.
\end{abstract}

Kata kunci: Interlanguage, Kalimat Tanya, Interlingual Transfer, Intralingual Transfer

\title{
Introduction
}

Teaching English in any grades of institutions cannot leave one element, which support the students' mastery that is grammar. It plays important roles to control students in using sentences or phrases. Their mastery in English grammar will make their sentences comprehensible 
and acceptable. The students are able to fit the words in sentences with others.

In syntactical construction the students have to know the appropriate form suits with meaning and context. The students understand that learning English needs to understand the rules of grammar. The grammar is integral part of learner's knowledge. It is related with other subject. Grammar is a body of empirical rules which explain and regulate the structure of English sentences. Structure serves as a guide for students in building English sentences correctly (Mahani and Siswantoro, 1987: 53).

The systematical rules of English grammar have become integral part of the students' knowledge. It will enhance them to provide English sentences that are grammatically acceptable and therefore comprehensible. Some rules are extremely complex, including question sentences. It is one of the subject matter that the students learn in school. There are three kinds of question sentences of English; they are yes-no question, interrogative words, and tag questions (Nuryanto, 1986: 118123). Seeing the kinds of question sentences above, it is understood that most of students find the difficulties in mastery of building and construction question sentences. It can be seen in the phenomenon such as: "Where we eat?" It should be: "Where do we eat?", or they may write "Who book own?" It should be: "Whose is it?"

Based on their English proficiency level, the students have learned about question sentences from junior up to senior high school. The students find many problems in building question sentence. Here the writer wants to elaborate the difficulties faced by the students in building questions and the sources of difficulties in building sentences. 


\section{Interlanguage of Second and Foreign Language Learners}

The term interlanguage (IL) was introduced by the American linguist Larry Selinker to refer to the linguistic system evidenced when an adult second language learner attempts to express meanings in the language being learned. The interlanguage is viewed as a separate linguistic system, clearly different from both the learner's 'native language' (NL) and the 'target language' (TL) being learned, but linked to both NL and TL by interlingual identifications in the perception of the learner. A central characteristic of any interlanguage is that it fossilizes that is, it ceases to develop at some point short of full identity with the target language. Thus, the adult second-language learner never achieves a level of facility in the use of the target comparable to that achievable by any child acquiring the target as a native language. There is thus a crucial and central psycholinguistic difference between child NL acquisition and adult second language (L2) acquisition: children always succeed in completely acquiring their native language, but adults only very rarely succeed in completely acquiring a second language. The central object of interlanguage research is to explain this difference - essentially, to describe and explain the development of interlanguages and also to explain the ultimate failure of interlanguages to reach a state of identity with the target language (Tarone, 2006: 747).

According to Richards (1992: 186), interlanguage is the type of language produced by second and foreign language learners who are in the process of learning a language. In language learning, learner's errors are caused by several different processes. These include: (1) borrowing patterns from the mother tongue; (2) extending patterns from the target 
language; and (3) expressing meanings using the words and grammar which are already known.

\section{Foreign Language Learner Difficulties}

In learning foreign language, learner will encounter some problems in mastering the rule of language. They often produce erroneous utterances whether in their speech or their writing. Exactly those problems are caused of differences between the rule of the mother tongue and the foreign language. So, this matter makes difficulties to them in learning the target language. One of the difficult terms related with this research is building question sentences. There are two sources of difficulties in building question sentences namely inter lingual transfer and intra lingual transfer. Inter lingual transfer is caused by the interference of the learners' mother tongue. Interference from the mother tongue is clearly a major source of difficulties in second language learning. In consequence, a lot of mistake in studying foreign language is caused by mother tongue. While intralingual is the negative transfer of item within the target language. Ricard states the intra lingual errors consist of four categories, namely (1) over generation, (2) ignorance, (3) incomplete application of the rules, and (4) semantic error (Richards, 1976: 35). Fourth of this big enough matter is influence in studying foreign language. In consequence, studying foreign language is very important to be emphasized on this matter.

\section{English Question Sentence}

Question can be divided into three major classes according to the types of answer that expect (Qirk, 1973: 191), they are yes-no question 
(that expect only affirmation or rejection), W-H question (that expect a reply supplying an item of information), and tag question (that invite the listener to respond the question).

1. Yes-no question

These are the simple questions elicit the answer yes or no only (Frank, 1972: 88). Usually all of these questions begin with an auxiliary or a single form of be that has been reversed with the subject.

2. Tag question

These are also yes-no question, but the special form into which they are put, shows of these two answers is actually expected. If the statement part of the question is positive, the question part is negative. If the statement part is negative, the question part is positive.

3. W-H question

These are questions that elicit specific information of a person, place, time, etc. As in negation, the verb in each of these questions is handled differently depending on whether the verb is or is not accompanied by an auxiliary in the declarative sentences. W-H questions are formed with the aid of the following interrogative words (question words), who for persons, whom for object, whose for possessive, which for things or subject or object (Thomson and Martinet, 1986: 71). Some experts also mention W-H question as interrogative word question, as Frank stated (1972: 88). 


\section{The Rules of Building Question}

\section{Yes-no Question}

The pattern of an interrogative sentences as follows: auxiliary + subject adverb + verb $+\mathrm{C} /$ Adjunct + modal .

Verbal Pattern

Examples: 1) Does your friend study hard? Yes, he does. / No, he doesn't.

2) Shall she give us the book? Yes, she shall. / No, she shan't.

Non-verbal Pattern

Examples:

1) Are the nurses always busy?

Yes, they are. / No, they aren't.

2) Is one of the students sick?

Yes, he is. / No, he isn't.

For the verbal pattern, there must be an agreement between subject and auxiliary used. When the subject is singular, it uses auxiliary does and verb with $s$ is omitted. For instance, there is a statement "She runs alone every morning.", its interrogative sentence will be "Does she run alone every morning?". The do auxiliary is accompanied with the simple present which follows its verb with $s$. For example, there is a statement "I have much money.". In interrogative sentence form will be "Do you have much money?" Then, modal auxiliary generally has no $s$ suffix for third person and no infinitive there is used for singular and plural subject. For example the statement "They can climb the mountain carefully.". It will be "Can they climb the mountain carefully?"

In addition to personal pronoun, the expletives there and it may also appear in a short answer to yes-no question. 
Is there my father? Yes, there is.

In negative yes-no question, not is contracted with the auxiliary that starts the question. In formal usage, not is placed in adverbial position right after the reversed auxiliary and subject.

Isn't Sari reading?

Is Sari not reading?
Didn't Sari read newspaper?

Did Sari not read newspaper?

In highly informal conversation, the auxiliary and the subject of a yes-no question are frequently omitted.

Get lunch?

Thinking serious problem?

serious problem? for Do you get lunch?

for Are you thinking

\section{Tag Question}

The tag question consists of operator plus pronoun, without a negative partite, if the super ordinate clause is positive, the tag is negative, and vice versa (Frank, 1972: 88-91). For example, "He likes his job, doesn't he?", the meaning of this sentence, like its form, involve a statement and question, each of them asserts something then invites the listeners response to it. Azar said that a tag question added at the end of a sentence (1993: 16). Speaker uses tag question chiefly to make sure their information is correct or seek agreement. Tag question may be spoken:

- With a rising intonation if the speaker as truly speaking to ascertain information, idea, believe, is correct. Example: Ann is in apartment, doesn't she? 
- With a falling intonation if the speaker is expressing an idea which is almost certain listener will agree. Example: It's nice day today, isn't it?

Tag question expects agreement with the statement (Frank, 1972: 89). It's containing the regular question auxiliary plus the personal pronoun that stand the subject. For example, "It's not raining, is it? No, it isn't."

Krohn writes his pattern (1984: 21) as follow:

Table 1. Non Verbal Tag Question

\begin{tabular}{|l|l|}
\hline \multicolumn{1}{|c|}{ Statement } & \multicolumn{1}{c|}{ Negative Tag } \\
\hline There are birds, & aren't there? \\
They are clever, & aren't they? \\
Tuti is diligent, & isn't she? \\
\hline
\end{tabular}

Table 2. Non Verbal Tag Question (negative statement)

\begin{tabular}{|l|l|}
\hline \multicolumn{1}{|c|}{ Negative Statement } & \multicolumn{1}{c|}{ Affirmative Tag } \\
\hline You aren't sick, & are you? \\
It is not your book, & is it? \\
Hari is not in the home, & is he? \\
\hline
\end{tabular}

Table 3. Verbal Tag Question

\begin{tabular}{|l|l|}
\hline \multicolumn{1}{|c|}{ Statement } & \multicolumn{1}{c|}{ Negative Tag } \\
\hline He went to school, & didn't he? \\
She runs alone, & doesn't she? \\
We write a letter, & don't we? \\
\hline
\end{tabular}


Table 4. Verbal Tag Question (negative statement)

\begin{tabular}{|l|l|}
\hline \multicolumn{1}{|c|}{ Negative Statement } & \multicolumn{1}{|c|}{ Affirmative Tag } \\
\hline Annie didn't read well, & did she? \\
Toni doesn't go to school, & does he? \\
They don't bring my book, & do they? \\
\hline
\end{tabular}

\section{Interrogative Word Question}

Interrogative word question is question begin with either interrogative adverb (why, when, where, how) or pronoun (who, whom, what, which) (Frank, 1972: 91). This type of question begins with a question word (such as who, what, when, or where), the rest of word order pattern is auxiliary is placed before the subject (Krohn, 1984: 67). Below is the usage spread:

- Who substitutes for a noun phrase which refers to a person.

- Who substitutes for a noun phrase which refers to thing.

- When substitutes for an adverbial which refers to time.

- When substitutes for an adverbial which refers to place.

- Why substitutes for part of the predicate phrase.

- The question words as substitutes for the subject.

(Note: Who in this pattern is informal standard English. It is used in conversation also in notes or letters to friends and relatives. Whom is formal standard English. It is used in speech and formal writing, such as papers which students write in college.)

Nuryanto notes that the question word question may function as the interrogative pronoun (1986: 21). The interrogative adverbs consist of 
when (adverb of time), where (adverb of time), how (adverb of manner) may be combined with preposition. For instance, the interrogative pronoun of who, what, whom, and whose are normally used for person. What is used for things, which is used for thing and person when a choice involved.

\section{The Use of Word Questions}

Azar gives some explanations about the use of word question (1981: 1-3) as in the table below:

Table 5. Kinds of Word Question and its Function

\begin{tabular}{|c|c|c|}
\hline $\begin{array}{c}\text { Word } \\
\text { Question }\end{array}$ & Function & Example \\
\hline When & $\begin{array}{l}\text { It is used to ask question } \\
\text { about time. }\end{array}$ & When will you come? \\
\hline Where & $\begin{array}{l}\text { It is used to ask question } \\
\text { about place. }\end{array}$ & $\begin{array}{l}\text { Where I get ticket for the } \\
\text { show? }\end{array}$ \\
\hline Why & $\begin{array}{l}\text { It is used to ask question } \\
\text { about reason. }\end{array}$ & Why do you go? \\
\hline \multirow[t]{4}{*}{ How } & $\begin{array}{l}\text { It is generally ask about } \\
\text { manner, but has many } \\
\text { idiomatic uses. }\end{array}$ & How does he drive? \\
\hline & $\begin{array}{l}\text { It is used with many and } \\
\text { much. }\end{array}$ & $\begin{array}{l}\text { How much money does it } \\
\text { cost? }\end{array}$ \\
\hline & $\begin{array}{l}\text { It also used with adjective } \\
\text { and adverb. }\end{array}$ & $\begin{array}{l}\text { How old are you? } \\
\text { How fast were you driving? }\end{array}$ \\
\hline & How long asks about & How long have you been in \\
\hline
\end{tabular}




\begin{tabular}{|c|c|c|}
\hline & length of time. & \multirow{2}{*}{$\begin{array}{l}\text { this city? } \\
\text { How often do you write in } \\
\text { home? }\end{array}$} \\
\hline & $\begin{array}{l}\text { How often asks about } \\
\text { frequency. }\end{array}$ & \\
\hline & $\begin{array}{l}\text { How far asks about } \\
\text { distance. }\end{array}$ & $\begin{array}{l}\text { How far is to Miami from } \\
\text { here? }\end{array}$ \\
\hline Who & $\begin{array}{l}\text { It is used ask the subject of } \\
\text { a question. }\end{array}$ & $\begin{array}{l}\text { Who wants to come with } \\
\text { me? }\end{array}$ \\
\hline Whom & $\begin{array}{l}\text { It is used ask the object of } \\
\text { a verb or preposition. }\end{array}$ & Whom did you see? \\
\hline Whose & $\begin{array}{l}\text { It is used ask the question } \\
\text { about possession. }\end{array}$ & $\begin{array}{l}\text { Whose book did you } \\
\text { borrow? }\end{array}$ \\
\hline \multirow[t]{3}{*}{ What } & $\begin{array}{l}\text { It is used at the subject of } \\
\text { a question. It refers to } \\
\text { things. }\end{array}$ & What made you are angry? \\
\hline & It is also used as an object. & What do you need? \\
\hline & $\begin{array}{l}\text { It sometimes accompanied } \\
\text { a noun. }\end{array}$ & $\begin{array}{l}\text { What classes are you } \\
\text { talking? }\end{array}$ \\
\hline
\end{tabular}

\section{The Interrogative Sentence with Auxiliaries}

There are three types of auxiliaries, each of them serve different purpose:

\section{Tense Auxiliary}

It consist of be, have, will, and shall. The tense auxiliaries perform a structural function only. Be occur with the -ing present participle in the 
progressive forms on the tenses and with $-e d$ in the passive tenses. Have is used for the perfect tense. Will and shall are used for the future tense.

\section{Do Auxiliary}

The do auxiliary is accompanied with the simple form of the verb (infinitive without to). It is used only in simple present tense (do or does offer) and simple past tense (did offer). It provides an auxiliary less verbs to enable then to function in the following grammatical patterns.

a. Question

Do you like a new hat?

b. Negative statement

I don't like your new hat.

c. Abridgment-omission or substation

I don't like your coffee and neither does my wife.

d. Emphasis

My teacher thinks I didn't study for my test, but I did study.

e. Entreaty

Do come to the party tonight.

\section{Modal Auxiliary}

Frank said that modal auxiliaries are added to the verb as special semantic component such as ability, obligation, and possibility (1981: 94). Some of them express the same kinds of semantic coloring of verbs in the subjective mood. In general, they have no $-\mathrm{s}$ suffix for third person and no infinitive of participle form. They have only two formal tenses, the present and the past, which are used with the simple form of the lexical verb. Modal auxiliary does not change their form for person or 
number, that is, there is $\mathrm{ni}-\mathrm{s}$ form for the third person singular. The modal position in the sentence is after the subject and before the rest of the sentence (Krohn, 1974: 109).

\section{Research Methodology}

The data of the research was taken from the students' sentences about yes-no questions, W-H questions, and tag questions which were made by the students in building question sentences through translation and complete the sentence according to each type of question. Their sentence was done through examination in the classroom of 40 second year students of MA As Soorkaty Salatiga along the research. The research was conducted on 1-12 June 2004 in the effective learning time from 07.00 a.m. to 01.00 p.m. The sources of data were taken based on the result of the test.

The research was conducted by quantitative and qualitative study respectively. A quantitative was used to calculate the number of errors of each kind of sentences. Than qualitative one was used to analyze the source of difficulties and its cause of errors. In this research, the writer used a test as the instrument in collecting the data. By giving the test, she wanted to know the difficulties that faced by the students in building question sentences construction. The total number of test were 20 items, consist of 5 yes-no questions, $5 \mathrm{~W}-\mathrm{H}$ questions, and 10 tag questions. The test was done by the students in a written essay form in the piece of paper prepared.

To make easier in classification of the test, the writer classified the data based on the kinds of English questions. She wrote and calculated the total number of errors of each kind of question sentences. 
Then, she tried to conclude the difficulties in building question sentences construction which are related to the question sentences element. At last, the writer analyzed the source of difficulties based on the final test result which were presented in percentage formula:

$$
\begin{array}{ll}
\mathrm{P}=\frac{F}{N} \times 100 \% & \mathrm{P}=\text { Percentage } \\
& \mathrm{F}=\text { Number of individual } \\
& \mathrm{N}=\text { Frequency (Anas, 1994: 40) }
\end{array}
$$

\section{Discussion and Finding}

Based on the analysis, the writer found that the students mostly done the errors on translating the meaning from native language to target language. They were remain used the words and grammar from the mother tongue. In the term of interlanguage, it was included in the third type of error that was expressing meaning using the words and grammar which are already known. The writer separated the difficult points into three points of description result, they were:

\section{The Difficulties in Building Yes-no Question Sentence}

In this type of question, the learners built yes-no question through translation. Based on the data involved, it can be analyzed that they have difficulties in building yes-no question through translation from Indonesia into English sentence, namely (1) apakah / what and (2) choosing to be. 


\section{Apakah / what}

In translation the word "apakah", the students have made error repeatedly. It is influenced by their mother tongue to translate "apakah". The learners tend to make addition, it is an error which characterized by the presence of an item which is not appear in a well form utterance. They tend to translate "apakah" in yes-no question sentences with the word "what". Such kind of error is categorized include into addition because the students rise an item which not appear in correct form of English contraction.

Examples : 1) Apakah mereka siswa MA As Soorkaty Salatiga?

2) Apakah kamu kemarin makan di restoran itu?

The students' translation: a) What are they student MA As Soorkaty Salatiga?

b) What are you eat in restaurant yesterday?

Seeing the students' translation above, the learners are very poor in translation mastery from Indonesia into English sentence. It is not similar to translate from Indonesia into English. The students prefer to use word "what" to translate Indonesian word of "apakah". It is not appear in well form utterance. The students should put auxiliary verb for the target language "apakah", so the correct forms are as follow:

1) Are they students MA As Soorkaty Salatiga?

2) Did you eat in restaurant yesterday?

\section{Choosing to be}

The second difficulties in building yes-no question sentences through translation is choosing to be on auxiliary verb with the subject used in the 
sentences. The learners are still obvious in using was, were, is, are, do, does, etc.

Examples : 1) Apakah mereka siswa MA As Soorkaty Salatiga?

2) Apakah dia seorang perawat?

The students' translation: a) What are they student MA As Soorkaty Salatiga?

b) What does she a nurse?

The learners do not pay attention in using to be from the example (a) the students made errors in choosing to be which must be related with the time or action happened. They should not put "are" for the example above, because the adverb of time which is used is past tense. In the example (b) the students also made error in choosing to be. They should not put "does" in the sentence, because the students above are not verbal pattern. They should put to be according to the subject used, so the correct sentence are:

1) Are they students MA As Soorkaty Salatiga?

2) Is she a nurse?

Table 6. The Result of Yes-no Question Translation from Indonesia to English

\begin{tabular}{|c|l|c|c|c|c|}
\hline No & \multicolumn{1}{|c|}{ Test Item } & \multicolumn{2}{|c|}{$\begin{array}{c}\text { The Sum and } \\
\text { Percentage of } \\
\text { Correct } \\
\text { Answer }\end{array}$} & \multicolumn{2}{|c|}{$\begin{array}{c}\text { The Sum and } \\
\text { Percentage of } \\
\text { Wrong Answer }\end{array}$} \\
\hline 1. & $\begin{array}{l}\text { Apakah dia seorang } \\
\text { perawat? }\end{array}$ & 15 & $37,5 \%$ & 25 & $62,5 \%$ \\
2. & Apakah kita datang ke & 10 & $25 \%$ & 30 & $75 \%$ \\
\hline
\end{tabular}




\begin{tabular}{|c|l|c|c|c|c|}
\hline 3. & $\begin{array}{l}\text { kantor kemarin? } \\
\text { Apakah kamu kemarin } \\
\text { 4. }\end{array}$ & 12 & $30 \%$ & 28 & $70 \%$ \\
5.kan di restoran itu? & $\begin{array}{l}\text { Apakah mereka siswa MA } \\
\text { As Soorkaty Salatiga? } \\
\text { Apakah kita akan belajar } \\
\text { bersama di rumahku } \\
\text { besok? }\end{array}$ & 17 & $42,5 \%$ & 23 & $57,5 \%$ \\
\hline
\end{tabular}

\section{The Difficulties in Building W-H Question Sentence}

In this type of question, the learners built W-H question through translation. Based on the data involved, it can be analyzed that they have difficulties in building W-H question through translation from Indonesia into English sentence, namely (1) choosing word question and (2) choosing to be.

\section{Choosing word question}

The learners of MA As Soorkaty Salatiga are still bad to translate from Indonesia into English. In this type of question, the word questions which are used should suit and relate with an adverb of time and place. There are some words question in English such as who, whose, whom, where, when, etc. each of them has function according to the right person. It is not correct to use "who belong" to transfer the meaning of "milik siapa". Examples : 1) Milik siapa buku ini?

2) Milik siapa buku-buku di sana? 
The students' translation: a) Who belong book is this?

b) Who belong books is there?

The students have mistakes in using the word question "whose". Many students use "who belong" to translate Indonesian words "milik siapa". It is influenced by their mother tongue to transfer from L-1 to L-2. They think to everything in L-1 "milik siapa" consist of two words, then they translate it word by word "who belong". The students tend to presence the items which are not appear in correct pattern, so the correct form will be:

1) Whose book is this?

2) Whose books are there?

\section{Choosing to be}

The second difficulties in building question sentences through translation is refer to choosing to be. Besides the learners have difficulties to use "who", they also make an error in choosing to be.

Example : Milik siapa buku-buku di sana?

The students' translation: Who belong books is there?

The learners' translation is still far from perfect. The learners should not put "is" in the form of plural noun. Such kind of error is made because they have not paying attention with "-s" added at the end of the word "books". They should put "are" for its to be, so the correct sentence will be:

Whose books are there?

Table 7. The Result of W-H Question Translation from Indonesia to English 


\begin{tabular}{|c|c|c|c|c|c|}
\hline \multirow{2}{*}{$\begin{array}{l}\text { No. } \\
1 .\end{array}$} & \multirow{2}{*}{$\begin{array}{c}\text { Test Item } \\
\text { Apa yang dia makan? }\end{array}$} & \multicolumn{2}{|c|}{$\begin{array}{c}\text { The Sum } \\
\text { and } \\
\text { Percentage } \\
\text { of Correct } \\
\text { Answer }\end{array}$} & \multicolumn{2}{|c|}{$\begin{array}{c}\text { The Sum } \\
\text { and } \\
\text { Percentage } \\
\text { of Wrong } \\
\text { Answer }\end{array}$} \\
\hline & & 14 & $35 \%$ & 26 & $65 \%$ \\
\hline 2. & Milik siapa buku ini? & 8 & $20 \%$ & 32 & $80 \%$ \\
\hline 3. & Milik siapa buku-buku di sana? & 14 & $35 \%$ & 36 & $65 \%$ \\
\hline 4. & $\begin{array}{l}\text { Kapan kamu mengerjakan PR } \\
\text { ini? }\end{array}$ & 20 & $50 \%$ & 20 & $50 \%$ \\
\hline 5. & $\begin{array}{l}\text { Berapa jam kamu belajar } \\
\text { dalam sehari? }\end{array}$ & 18 & $45 \%$ & 22 & $55 \%$ \\
\hline
\end{tabular}

\section{The Difficulties in Completing Tag Question Sentence}

In this type of question, the learners completed the tag question follow the sentences. Based on the data involved, it can be analyzed that they have difficulties in completing the tag question follow the sentences, namely choosing auxiliary verb.

\section{Choosing auxiliary verb}

The learners are still obvious and confuse in using suitable auxiliary verb based time form in the sentences, such as is, am, are, do, does (present), was, were, did (past), will, shall, should, etc. (future), etc.

Examples : 1) You like coffee,...?

2) They arrived yesterday, ...?

The student's translation: a) You like coffee, doesn't you?

b) They arrived yesterday, don't they? 
The learners do not pay attention in using auxiliary verb. From the example (a) the students made error in choosing auxiliary verb which must be related with the time or action happened. They should not put "does" for the example above though the adverb of time indicates of present tense form. They did not consider that the subject is "you". It is a plural subject, so the proper auxiliary is "do". In the example (b) the students also made error in choosing auxiliary verb. They should not put "do" in the negative tag, because the adverb of time which is used is in past tense, so the correct sentences are:

1) You like coffee, don't you?

2) They arrived yesterday, didn't they?

Table 8. The Result of Completing Tag Question Based on Sentences

\begin{tabular}{|c|l|c|c|c|c|}
\hline No. & \multicolumn{1}{|c|}{ Test Item } & \multicolumn{2}{|c|}{$\begin{array}{c}\text { The Sum } \\
\text { and } \\
\text { Percentage } \\
\text { of Correct } \\
\text { Answer }\end{array}$} & \multicolumn{2}{|c|}{$\begin{array}{c}\text { The Sum } \\
\text { and } \\
\text { Percentage } \\
\text { of Wrong } \\
\text { Answer }\end{array}$} \\
\hline 1. & They arrived yesterday, ...? & 20 & $50 \%$ & 20 & $50 \%$ \\
2. & You have heard about that, ...? & 25 & $62,5 \%$ & 15 & $37,5 \%$ \\
3. & You like coffee, ...? & 18 & $45 \%$ & 22 & $55 \%$ \\
4. & I may speak to him, ...? & 16 & $40 \%$ & 24 & $60 \%$ \\
5. & You'd rather I didn't say anything, ...? & 17 & $42,5 \%$ & 23 & $57,5 \%$ \\
6. & He didn't have to speak to me, ...? & 25 & $62,5 \%$ & 15 & $37,5 \%$ \\
7. & I have to buy some matches, ...? & 14 & $35 \%$ & 26 & $65 \%$ \\
8. & He was not fall down, ...? & 27 & $67,5 \%$ & 13 & $32,5 \%$ \\
9. & You will come, ...? & 21 & $52,5 \%$ & 19 & $47,5 \%$ \\
10 & You would like the window to open, ...? & 20 & $50 \%$ & 20 & $50 \%$ \\
& & & & & \\
\hline
\end{tabular}


From the finding result above, it can be conclude that there are two sources of difficulties in building question sentences namely interlingual transfer and intralingual transfer.

\section{Interlingual Transfer}

The learners have made interlingual error because of the mother tongue interference. They usually transfer the system of their mother tongue into foreign language in placing what for the each want “apakah".

Examples :

1. False : What is she a nurse?

True : Is she a nurse?

2. False : What we will study together in my house?

True : Do we will study together in my house tomorrow?

From the examples, these are transfer from L-1 (first language / mother tongue). The errors are such kind of interlingual transfer, because the students admit one of the element of the correct sentences in building yes-no question.

\section{Intralingual Transfer}

It is the negative transfer of items within the tongue language or put another way the incorrect generalization of the rule within the target language. It has been found that the early stages of language are characterized by a predominance of interlingual transfer is manifested. Negative intralingual transfer can be illustrated in utterance.

Examples :

1. False : Who belong books is this? 
True : Whose book is this?

2. False : When you do homework?

True : When do you do this homework?

According to Dulay, the constructive diction where the structure in the first language would be product (1982: 97). It is influenced by the first language habit. In other word, the students' difficulty is by an interference of the learners that are used to think himself by using their mother tongue. The sentences above are errors in the use of grammar because the students still cannot recognized the subject and put "are" for its to be.

\section{Conclusion}

Based on the analysis, the result shows some conclusions. Firstly, the researcher finds the types of difficulties problems are faced by the students in building question mastery, such as: (1) building yes-no question sentences in translation the word "apakah", that is related with the use of to be. (2) Building interrogative word question sentences in translation the words "apa”, "kapan", "milik siapa”, etc. That are related with the use of "what", "when", "whose”, etc. (3) Completing the tag question sentences with the proper auxiliary based on tense of the sentences. Those are related with choosing suitable to be or auxiliary. The most difficulties in building question sentences are especially in yesno question form by using the word "apakah". The source of difficulties which have been analyzed are mostly caused by inter lingual and intra lingual transfer. The errors of inter lingual transfer is affected by the students' mother tongue interference. It is a major source of difficulty in second language learning. While the errors of intra lingual transfer is 
caused by the students' lack of knowledge about grammar. In the term of interlanguage, the students' errors are mostly included in expressing meaning by the words and grammar of their mother tongue.

\section{References}

Azar, Betty Schrampfer. 1993. Understanding and Using English Grammar. Prentice Hall Regent: New Jersey.

Dulay. 1982. Language Two. Oxford University Press. New York.

Frank, Marcella. 1972. Modern English: a Practical Reference Guide. Englewood Cliffs: New Jersey. . 1981. Modern English: a Practical Reference Guide.

Englewood Cliffs: New Jersey.

Krohn, Robert. 1984. English Sentence Structure. The University of Michigan Press: New York.

Mahani, Setyo and Siswantoro. 1987. Pengkajian Kurikulum SMA. Universitas Sebeles Maret: Surakarta.

Murphy, Raymond. 1985. English Grammar in Usage. Cambridge University Press: Cambridge.

Nuryanto. 1986. Essential of English Sentence Structure. Yayasan IKK: Yogyakarta.

Qirk. 1973. A University Grammar of English. Longman: England.

Richards, Jack C. 1976. Error Analysis. Columbia University Press: New York.

et.al. 1992. Dictionary of Language Teaching \& Applied Linguistics. Longman: UK.

Sudjiono, Anas. 1994. Pengantar Statistik Pendidikan. Raja Grafindo: Jakarta.

Tarone, E. 2006. Interlanguage. University of Cartenbury: New Zealand. Thomson, A. J. and A.V. Martinet. 1986. A Practical English Grammar. Oxford University Press: Hongkong. 